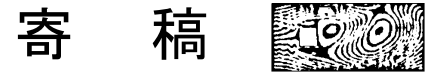

\section{日本風工学会名誉会員に推挙されて On the Nomination for a Honorary Member}

岡島 厚*

Atsushi OKAJIMA

5 月 24 日開催の平成 23 年度日本風工学会 $\cdot$ 社員総会 (大阪市立大学・杉本キャンパス) において, 日本風工 学会名誉会員に推挙されました。大一ん名誉なこと，学 会員の皆様に厚くお礼申し上げます。

風工学の分野における円柱や矩形断面柱などの基本断 面構造物の流力特性および渦励振やフラッタなどの流力 振動の解明, 特に高いレイノルズ数における構造物の流力 振動は，ますます重要なテーマの 1 つと考える。1960 年頃 までは, いわゆる臨界レイノルズ数以上の高いレイノルズ 数流れの研究がそしく, この領域におけるカルマン渦の存 在も明確ではなかった。しかし実際には強風時で振動する 煙突の観察などが発端となり，Anatol Roshko は，当時 Caltech で廃棄される大型低速風洞の最後の風洞実験で臨 界レイノルズ数以上の非常に高いレイノルズ数領域の極 めて貴重な実験を行った。そして円柱の圧力分布や抗力係 数, 後流渦のストローハル数を測定して後流渦の存在を実 証した(1)。そしてこのレイノルズ数領域を A. Roshko と故 谷一郎先生は‘Transcritical Region’と命名した（1961 年）。 しかし, M. M. Zdravkovich の著書 Flow around Circular Cylinders にあるように，この‘Transcritical’の言葉は誤解さ れ易く, A. Roshko 自身もそれを認めており, H. H. Pearcey による'Postcritical'が適切とされ使用されている。また，そ の邦語訳は, 故谷一郎先生によって「極超臨界域」と命名 された(2)。このような臨界レイノルズ数以上の臨界域や極 超臨界域における構造物の渦励振など流力振動特性の確 立は，今日でも新鮮な研究テーマである。元来，極超臨界 域の振動実験は非常に難しく, 表面粗さを導入して円柱表 面境界層の遷移を促進させて比較的低いレイノルズ数で 疑似的に極超臨界域を実現させ，低風速で振動を可能にし て極超臨界域の振動実験を試みた(3)。その結果, 渦放出が
ない超臨界域，再び渦放出が現れる極超臨界域を比較的低 レイノルズ数で実現し, 流れ方向振動は超臨界域でも発生 し，直角方向の渦励振は超臨界域では発生せず，極超臨界 域で生じることなど流力振動特性を明らかにした。

さて, 本年 3 月 11 日に発生した東日本大震災と東京電 力福島第一原発の事故は，この国の将来のエネルギー問 題ばかりでなく，この国の科学技術の施策についても再 考されなければならない。原子力エネルギーの大幅な削 減も余儀なくされ, 風力エネルギー, 太陽光エネルギー, バイオマスエネルギーなどの再生可能エネルギーの普及, 自動車の燃費改善, 建築物や電化製品の省エネ性能向上 などの新しい技術の発展と普及が重要となる。特に, 風 力発電は, 日本風力発電協会も指摘しているように, 素 材開発・加工技術・IT 制御など日本の比較的得意分野の 技術が詰まっている。高度な造船技術を駆使してこの市 場に食い込めば新たに雇用機会も増えることも期待され る。環境省によれば，世界各国で出願された 4 万 7000 件 余りの再生可能エネルギーに関する特許のうち, 日本で 出願された特許件数が全体の $55 \%$ を占めるという。新技 術の実用化に向けた幅広い展開が期待される。

学際的学会である日本風工学会には, 種々な分野から いろいろな研究テーマや課題が持ち込まれている。風工 学会こそ学会員がともにそれらの問題を共有することに よって高いレベルで効率的に問題解決ができるものと考 える。本学会の今後の一層の発展を願ってやみません。

(1) Roshko, A., Journal of Fluid Mechanics, 10, pp. 345-56, 1961

(2) 谷一郎先生との私信

(3) Okajima, A., ほか 3 名, Journal of Fluids and Structures, 13-12, pp. 853-864, 1999. 12

* 金沢大学 名誉教授

Professor Emeritus, Kanazawa University 